University of Arkansas, Fayetteville

ScholarWorks@UARK

Education Reform Faculty and Graduate

Students Publications

Education Reform

5-6-2019

\title{
Is Collegiate Political Correctness Fake News? Relationships between Grades and Ideology
}

\author{
Matthew Woessner \\ Pennsylvania State University at Harrisburg \\ Robert Maranto \\ University of Arkansas, Fayetteville \\ Amanda Thompson \\ University of Georgia
}

Follow this and additional works at: https://scholarworks.uark.edu/edrepub

Part of the Educational Assessment, Evaluation, and Research Commons, Educational Leadership Commons, and the Other Educational Administration and Supervision Commons

\section{Citation}

Woessner, M., Maranto, R., \& Thompson, A. (2019). Is Collegiate Political Correctness Fake News? Relationships between Grades and Ideology. Education Reform Faculty and Graduate Students Publications. Retrieved from https://scholarworks.uark.edu/edrepub/82

This Article is brought to you for free and open access by the Education Reform at ScholarWorks@UARK. It has been accepted for inclusion in Education Reform Faculty and Graduate Students Publications by an authorized administrator of ScholarWorks@UARK. For more information, please contact scholar@uark.edu. 


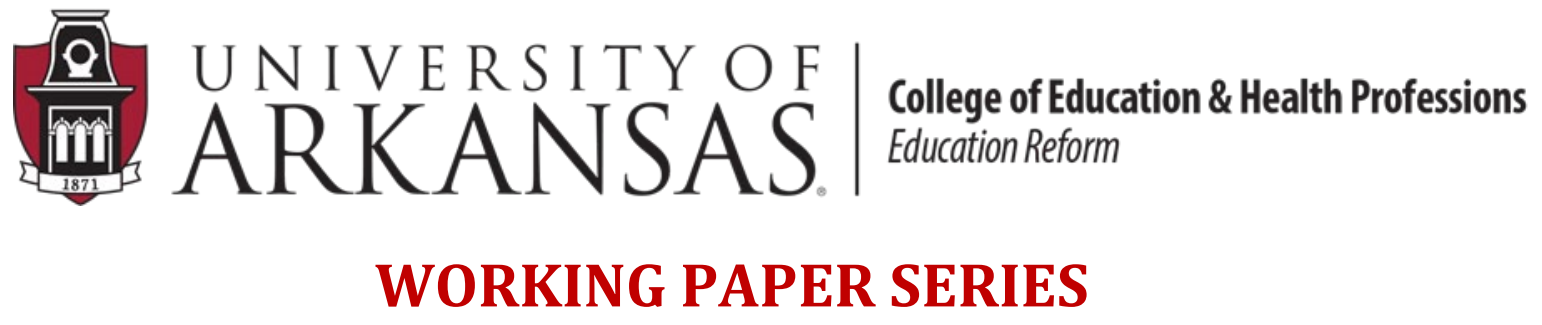

\title{
Is Collegiate Political Correctness Fake News? Relationships between grades and ideology
}

\author{
Matthew Woessner \\ Penn State University, Harrisburg \\ Robert Maranto \\ University of Arkansas \\ Amanda Thompson \\ University of Georgia
}

April 8, 2019

EDRE Working Paper 2019-15

The University of Arkansas, Department of Education Reform (EDRE) working paper series is intended to widely disseminate and make easily accessible the results of EDRE faculty and students' latest findings. The Working Papers in this series have not undergone peer review or been edited by the University of Arkansas. The working papers are widely available, to encourage discussion and input from the research community before publication in a formal, peer reviewed journal. Unless otherwise indicated, working papers can be cited without permission of the author so long as the source is clearly referred to as an EDRE working paper. 


\title{
Is Collegiate Political Correctness Fake News? Relationships between grades and ideology
}

\author{
Matthew Woessner, Penn State/Harrisburg \\ Penn State University, Harrisburg \\ School of Public Affairs, 777 West Harrisburg Pike \\ Middletown, PA 17057-4898 \\ (717) 948-6489; mow10@psu.edu \\ Robert Maranto, University of Arkansas, \\ EDRE, 201 Graduate Education
}

Fayetteville, AR, 72701; rmaranto@uark.edu; 610-299-3683

Amanda Thompson, University of Georgia

Department of Psychology, thompsonaj29@gmail.com>

\begin{abstract}
While considerable quantitative research demonstrates ideological liberalism among American professors, only qualitative work examines whether this affects undergraduate education. Using the HERI dataset surveying students in their first and fourth years in college $(n=7,207)$, we use OLS regressions to test whether students' political beliefs are associated with reported college grades and perceived collegiate experiences. We find that while standardized test scores are the best predictors of grade point average, ideology also has impacts. Even with controls for SES, demographics, and SAT scores, liberal students report higher college grades and closer relationships with faculty. Nevertheless, conservative students consistently show higher levels of satisfaction with college courses and experiences, and higher high school grades. We discuss implications.
\end{abstract}

Keywords: ideology, grading, higher education, undergraduate education, political correctness 


\section{Is Collegiate Political Correctness Fake News? Relationships between grades and ideology}

\section{Introduction}

Researchers have thoroughly investigated relationships between standardized test scores (i.e., SAT and ACT), high school grades, and college grades (Chapman, Fiscella, Duberstein, Kawachi and Muennig 2014; Schwartz 2015). Evidence suggests that standardized tests are reliable predictors of GPA in college, strengthened when used in tandem with high school GPA (Saket et al. 2012; Westrick et al. 2015). Test score and GPA differences across race, sex, and social class are well-documented (Chapel and Overton 2002; Titus 2006). Yet no prior research has explored whether student ideology affects high school or college grades.

Relationships between IQ scores and political ideology are well-documented in the U.S and elsewhere (Carl 2014; Heaven, Ciarrochi and Leeson 2011). Some researchers posit an association between academic success and political ideology as a function of the preferences and personality traits typically associated with the latter. For example, students with higher levels of liberal values more frequently present with traits such as creativity and inquisitiveness, which are thought to propel success in higher education (Deary, Batty and Gale 2008; Gerber, Huber, Doherty and Dowling 2011). Students with higher levels of conservative values more frequently present with traits such as conscientiousness (Gerber, Huber, Doherty and Dowling 2011; Tough 2012), as well as relative cognitive closure and respect for authority (Jost, Napier, Thorisdottir, Gosling, Palfai and Ostafin 2007), traits valued in traditional public school settings given the ideology of schooling and the perceived need for order so students can learn (Arum 2003; Hammack 2016). Further, these traits and ideological values typically align with both social class and political ideology, in part reflecting home environments and child rearing practices (Haidt 2012; Lareau 2003).

Interestingly, some research indicates that ideological stereotypes actually have greater impacts than ethnic stereotypes (O'Donohue and Redding 2009). Further, as with ethnic interactions, exposure to those of different ideals can promote more balanced and realistic schemas and reduced social conflict. Indeed Lukianoff and Haidt (2018) present a book length argument marshalling the psychological evidence for this. Unfortunately, research finds limited political diversity in higher education, increasingly among students, but to a far greater degree among faculty (Lukianoff and Haidt, 108-13, 121; Rothman and Lichter 2009). Accordingly, this research will investigate whether political ideology affects student academic outcomes and satisfaction.

Using the HERI surveys of American students in their first and fourth years in higher education, which include grades and standardized test scores $(n=7,207)$, we use OLS regressions to test whether student political ideology shows statistical relationships with grades and perceived college experiences. Findings indicate that while standardized test scores show the most statistical power in predicting GPA, ideology also has impacts, with conservative students having higher than predicted high school grades and lower than predicted college grades, findings that could reflect ideological bias or institutional fit, with 
conservative values such as conformity and institutional loyalty more valued in high schools than in colleges, which are more apt to value creativity.

\section{Theory and Hypotheses}

We theorize that collegiate majors with the greatest ideological homogeneity will present with the strongest predictive differences in student outcomes across ideology. Since professors in the humanities and social sciences lean well to the left of those in other disciplines (Author Reference A; Gross 2013; Lukianoff and Haidt, 108-13; Rothman and Lichter 2009), conservative students majoring in these disciplines may experience the greatest grading discrepancy. Notably, fieldwork at American universities indicates that conservative students (Binder and Wood 2013) perceive (liberal) ideological bias in grading as a serious concern, as do certain non-conservative intellectuals (Lukianoff and Haidt 2018; Weiss 2017). Regardless of whether left-leaning students are favored in the academy, these perceptions affect the legitimacy of higher education. If certain lawmakers believe that higher education is politically hostile to them, it may affect their willingness to fund public higher education, and to accept the expertise therein (author reference D). Yet prior research has not examined this question. We hypothesize that, given higher education's political orientation, even controlling for academic ability (as measured by standardized test scores) and demographic variables, student ideology will be related to grade point averages (GPAs):

H1. Controlling for standardized test scores, by the end of their college career, self-identified conservative students will have lower GPAs than their liberal peers.

Conversely, we do not predict such relationships with high school grades. A substantial qualitative and historical literature (Callahan 1962; Powell, Farrar and Cohen 1985; Rousemaniere 2013) indicates that traditional public high schools are oriented less toward intellectual inquiry and social change than toward social reproduction and non-academic pursuits such as athletics and social activities. Indeed nationally, 53\% of male school principals (and a higher percentage of male school superintendents) are former athletic coaches (Author Reference C). Accordingly, we do not propose that ideology will affect high school grades in the hypothesized direction; statistical relationships, should they exist, may take the opposite direction.

Given the inherent objectivity of undergraduate academic work, there are reasons to expect relationships between ideology and student grades to be muted. Professional norms encourage educators to interact with and grade students based on relatively objective work rather than ideological affinity of any kind. Merit is an important value to higher education faculty (American Association of University Professors 2007; Posselt 2016; Warikoo 2017), particularly in disciplines like economics and political science (Gross 2013; Shields and Dunn 2016). Accordingly, even if academia's left-leaning faculty were to favor students with liberal beliefs, we should expect differences in student outcomes to be subtle, explaining only limited statistical variance. Seemingly objective factors like standardized test scores should account for most of the explained variance in college grades. 
Within higher education, there is quantitative evidence that libertarians are tolerated, but social conservatives (who often embrace traditional religious views) have greater difficulty securing posts at prestigious institutions (Rothman and Lichter, 2009). Research indicates that few professors hold social conservatives in high esteem, while showing more receptivity to economically conservative (libertarian or classical liberal) thinkers. Indeed, data and qualitative work suggest that whole disciplines such as Sociology are characterized by antipathy toward social conservatives (Gross 2013; Posselt 2016; Yancey 2011). Accordingly, we hypothesize that beyond broad (liberal and conservative) ideological classifications, students embracing socially conservative positions may have lower grades than peers endorsing socially liberal positions:

H2. Controlling for standardized test scores, by the end of their college career, students endorsing socially conservative views will have lower GPAs than peers endorsing socially liberal views.

As much of the discussion above suggests, there are substantial ideological differences across academic disciplines, with ideology likely mattering more in the social sciences and humanities than in STEM (science, technology, engineering, and mathematics) disciplines. As noted above and suggested by Menand (2010), the latter may show greater ideological diversity in part since better markets for job-seekers mean fewer pressures to conform to majority views. Accordingly, we propose:

H3. To the degree that ideological beliefs predict GPA, effects will be more pronounced in the social sciences and humanities than in STEM and professional majors.

Finally, there is some quantitative and qualitative evidence of greater ideological conformity in more elite higher education institutions, both among faculty (Klein and Stern 2009; Menand 2010) and students (Warikoo 2017). Reeves and Halikias (2017) report empirical evidence that the more prestigious the college, the more likely it will adopt codes restricting speech; see also Whittington (2018) and Lukianoff and Haidt (2018). Accordingly, gaps in achievement for conservatives may be greater at more elite institutions; thus:

H4. To the degree that ideological beliefs predict GPA, the effects will be more pronounced at more elite institutions.

What follows are tests of these hypotheses.

\section{Methods}

The Cooperative Initiative Research Program (CIRP) is a well-known comprehensive source of longitudinal data collected by the Higher Education Research Institute (HERI). This survey encompasses various aspects of the collegiate experience including mental health issues and political attitudes. Data are collected from a range of colleges and universities across the United States providing a nationally representative sample of students. 
The longitudinal student survey data tracking respondent attitudes over four years is based on the results of the 2009 CIRP freshman survey (TFS) and the 2013 CIRP College Senior Survey (CSS). The combined TFS-CSS data includes 17,667 students at 156 campuses who completed both the freshman and senior surveys at the same institution. ${ }^{1}$ Student data in the joint TFS-CSS survey includes additional information about each respondent's college including its size, and Carnegie classification.

Both the TFS and CSS surveys ask students about their background, attitudes, and experiences (HERI 2018a, HERI 2018b). The CSS senior survey collects additional information about each respondent's college experience. Where the HERI posed the same questions about politics and policy in both the freshman and senior survey, were we were able to measure shifts in political attitudes over time. Additionally, both surveys include a question about the respondents' ideological orientation on a five-point scale ranging from "far left" to "far right."

College seniors preparing to graduate may take the CSS prior to departure. For our purposes, only four-year universities were included in the analyses from both the TFS and CSS respectively. This excluded community colleges, junior colleges, and technical colleges. Included in the CIRP TFS are sociodemographic data from students and their parents. Given possible impacts of SES on hypothesized relationships, we controlled for SES and parental political affiliation.

SES was categorically estimated for each mother and father through student-reported parental occupation, classifying values as high, moderate, or low by matching the studentreported occupation to aggregate data from the Federal Election Contribution (FEC) data compiled by Verandt Labs. Further, student-reported parent occupation is used to assign parent political affiliation using probability ratios. Each parent was assigned a probability of voting for the Democratic candidate ranging from $0-100 \%$ based on student-reported occupation of parent. For those occupations not explicitly represented in Verandt Lab's dataset, occupations were matched to the closest occupation available. While occupation is not a perfect predictor of party affiliation, it is reliable.

Accordingly, using student survey data from HERI, we will test quantitatively whether individual ideology correlates with undergraduate GPA, thus testing $\mathrm{H} 1$ and H2. To determine if ideology matters more in the social sciences and humanities (H3), we will run a series of independent models broken down by student major. Hypothetically, conservatives studying in more ideologically homogenous (liberal) majors might face more unique challenges than those in more ideologically diverse majors. Finally, if ideology is correlated with overall grades, we will test whether such effects are most pronounced at elite universities (H4), which seemingly have the most liberal faculty (Rothman et al. 2011).

${ }^{1}$ We analyzed the subset of respondents at four year colleges and universities who answered each of the 15-20 questioned included in the full model. Students at other institutions or who declined to disclose their SAT scores, their sex or other variables used to estimate student grades were excluded from analyses. 


\section{The Empirical Tests}

We constructed a series of regression models to predict students' reported GPA in high school and college. Although our hypotheses test the impacts of ideology on college grades, when possible we also examined models of high school GPA for comparison. Self-report data collected from students regarding GPA has been found valid and reliable across grade and subject (Sticca et al., 2017). Importantly, self-reported GPA is least reliable among students at the lower end of the GPA scale (Kuncel, Credé and Thomas 2005). The HERI dataset does not include students who do not continue from their freshman year to senior year, lessening such concerns.

\section{[Table 1 Here]}

Table 1 provides a simple overview of reported student grades broken down by respondents' ideological self-placement and their views on political/policy questions provided in the first wave of the panel study. The self-reported grades are based on the dataset's coding scheme wherein a " $\mathrm{D}$ " equals 1 and an "A/A+" equals 8 , rather than the $0-4$ values assigned to GPAs.

Results in Table 1 demonstrates how, as one might expect, students report a drop in overall grades when moving from high school to college. The average student scored a 6.85 on the eight-point scale in high school; 6.2 when nearing the end of college. Given the presumably harder college work and in many cases the challenge of being away from home, this decline is to be expected. Consistent with prior research (Woessner and Kelly-Woessner 2009), students who think of themselves as ideologically centrist report lower grades than either liberals or conservatives.

Results from this simple two-dimensional analysis lend some credence to the possibility that conservative see a sharper decline in their grades moving from high school to college. While the changes are not dramatic, never exceeding a two tenths of a point difference between the Left and the Right, it raises the prospect that conservatives may face some special challenges as they complete the four-year degree. For example, looking to selfreported assessments of ideology, students on the right exhibit a 0.68 decline in grades from high school to college while students on the left see only a 0.58 decline. Similarly, students who strongly oppose abortion rights see a 0.71 decline in grades while peers who express strong support see a 0.55 decline $^{2}$. Opponents of same sex marriage she sharper declines than strong supporters. Significantly, other political/policy questions provide no meaningful evidence for differences in grades. Student support for affirmative action appears unrelated to their transition from high school to college. If students' political views coming into college do have an impact on their college success, impacts are modest and apply to issues selectively.

To move beyond a simple difference of means test, we examined reported high school and college grades as a function of standardized test scores, SES/demographics, and different

2 It is noteworthy that, those who somewhat agree, slightly disagree or strongly disagree with abortion rights report an almost identical decline in grades. 
measures of ideology. Whereas a difference of means test can only account for overall differences between the Left and the Right, regression models permit us to account for ideology/political positions while accounting for differences in students' ability and background. This is a far more robust test of whether right leaning students have special obstacles in college.

In all four models, the first three variables labeled "Standardized Tests" (SATs) are by far the strongest overall predictors of grades, in both high school and college. Not surprisingly, these merit variables capture most of the explained variance in each of the four models listed in Table 2. Students who earn higher math, verbal and writing SATs earn far higher GPAs. Standardized testing is a better predictor of high school grades than college grades. Though less important statistically than SATs, gender and race also predict grades, with women and whites having somewhat higher GPAs than men and minorities, controlling for standardized test scores. Interestingly, the importance of standardized test scores declines from high school to college senior year, but that of race and sex increases.

Looking to the independent variables labeled ideology/party identification (PID), we find evidence for associations between grades and ideology. In the first column, we see that for high school, students who identify as more liberal tend to have lower GPAs. Neither ideological strength nor the estimated partisan leanings of the parents predict respondent high school grades. In the second column, for college, we see the reverse. The ideology variable is positive, meaning that by the fourth year of college, liberal students tend to have higher grades than conservative peers: ideological self-placement is the only variable in the model changing direction from high school to college. Additionally, students whose fathers align with the Democratic Party tend to have higher fourth year college grades. However, models of student policy positions in the third and fourth columns tell a more nuanced story.

Measuring student political views from self-identified ideological placement on a simple one-dimensional continuum may mask complex, and seemingly contradictory beliefs. As Converse (1964) and Jacoby (1991) show, the mass public rarely adopts ideologically consistent political attitudes. In answering one survey item, a respondent might assert that dissent is critical to the political process, but in the next item, the respondent might support efforts to ban racist or sexist speech. By measuring individual issue positions, rather than ideology, the models can reveal ideological advantages that simultaneously run in opposite directions.

In the model of high school grades shown in the third column, three of the six political variables are statistically significant, indicating that accounting for all other variables, positions on these issues influence GPA. Consistent with the ideological model of grades, which shows that conservatives earn higher grades than liberals, we find that in high school, respondents opposing abortion earn higher GPAs than do peers who support abortion. Policy items are all measured on the same six-point scale, and with a coefficient of -0.113 , abortion is the most important political variable in the model. Notwithstanding the GPA advantages held by conservative students in high school, students who support banning racist/sexist speech, and who endorse dissent as critical to the political process (positions typically associated with liberalism) enjoy a relative advantage over their peers.

The policy-based model of college GPA in the fourth column provides clues as to why, by the end of their senior year, liberal students report higher GPAs than conservative 
peers. Based on the model, pro-life students do not suddenly underperform their pro-choice counterparts. Except for the affirmative action variable moving from insignificant to significant, the same basic ideological trends remain. Whereas the advantage enjoyed by prolife students declines, the advantage of those who would ban racist/sexist speech or who value dissent grows.

Findings that conservative students report higher end of high school GPA, but subsequently lose their advantage by the end of college, are consistent with (but by no means prove) bias in favor of liberal students in college (and perhaps conservatives in high school) in grading, offering tentative support for H1. Yet these findings are far from conclusive. Shifts in academic performance among conservative students could be byproducts of leaving more controlled high school environments. One could imagine that students from conservative or religious household might face difficulties in the transition to college, losing the structure and community they enjoyed in high school. Fieldwork indicates that such transitions are easier for students from liberal, secular households, particularly upper SES households (Armstrong and Hamilton 2013; Rosen 2007). Generally, we must acknowledge the complexity of findings. Most notably, students endorsing the socially conservative (prolife) position have a significant grade advantage in high school, which declines, but does not disappear, in college; this decline may offer very modest support for H2. Generally, the prolife grade advantage may be associated with greater deferred gratification among socially conservative students (Arum and Roksa 2011), or social connectivity among students in Christian groups (Nathan 2005), either of which might foster academic success.

If the relative decline in grades for conservative students (including pro-life students) on moving from high school to college reflects the challenge of leaving structured home environments, we would expect the decline to occur uniformly among pro-life students in all disciplines. If the gap instead reflects ideological bias of some sort, the relative decline in grades would be most acute in disciplines where faculty are more liberal and less pronounced in those where faculty are more ideologically diverse, as predicted in $\mathrm{H} 3$.

\section{[Table 3 Here]}

Table 3 provides a series of models of high school and college grades broken down by major field arranged roughly in order from those with the most liberal faculty to the most moderate faculty according to Rothman, Kelly-Woessner and Woessner (2011). This includes the arts and humanities, social sciences, professional majors and natural sciences. While models which include ideological self-placement, like those included in Table 2, are useful in describing the overall impact of ideology, the models in Table 3 focus on individual political/policy views. This helps us paint a more nuanced picture of the possible relationships between student beliefs and educational outcomes.

Like the results in Table 2, standardized test scores account for a vast majority of the explained variance in the model, that is, most of the differences among students in grades. Again, sex and race are consistent predictors of grades. One of the strongest predictors of higher grades (outside of the standardized test scores) are students' views of abortion, with prolife students predicted to have higher grades than pro-choice students. Like the aggregate models in Table 2, pro-life students tend to have slightly higher grades than pro-choice students, both in high school and college. Consistent with H3, the pro-life advantage tends to decline most dramatically in the liberal fields like the humanities and social science. There is 
no appreciable decline in the professional fields, and an increase in the advantage in the natural sciences.

Just as the concentration of left-leaning faculty varies by discipline, there are varying rates of professorial liberalism depending on the prestige of the college. More prestigious institutions have higher concentrations of liberal faculty than lower ranking institutions (Author Reference A; Gross 2013). If the decline in pro-life student GPA advantage relates to the political disposition of the faculty, the most significant shift in the importance of the "abortion should be legal" variable should occur in more prestigious colleges and universities.

\section{[Tables 4 and 5 Here]}

Table 4 provides a series of models of high school and college grades broken down by college rankings, as defined in the HERI dataset. As with the prior table, these regression estimates model grades based on political/policy positions rather than broad measures of ideological self-placement. When broken down by college rankings, the models mirror most of the results seen in the aggregate model listed in Table 2. Standardized testing still constitutes the bulk of the explained variance in predicting grades. The breakdown by rankings does reveal some interesting differences. Among schools ranked " $<$ high" verbal SAT scores are not statistically significant, and writing SAT scores are only modestly correlated with overall grades. This suggests that the strong correlation between standardized testing and overall grades is more important among elite institutions than less prestigious schools.

The breakdown of the aggregate in Table 4 reveals that the grade advantage enjoyed by pro-life students differs substantially by institutional prestige. In the overall model we found that pro-life students were more likely (holding all else constant) to earn higher grades than pro-choice students. By the end of college, this predicted advantage dropped substantially. Among low to medium prestige schools $(<$ High) the pro-life student's advantage increased, nearly doubling in four years. Much like the aggregate model in Table 2 , the advantage of pro-life students in the "high" ranking schools dropped in four years. Among the 'Very High' ranked schools the advantage is not even statistically significant.

These results are consistent with H4, which posits that the impact of ideology will be more significant at elite schools. Given that faculty tend be far more liberal at more prestigious institutions, it raises the possibility that faculty ideology may play a role moderating the effect of student beliefs on grades.

It is important to note that, while the abortion variable changes in a manner consistent with the political-bias hypothesis, other variables are less predictable. Items gauging student support for same sex marriage and concerns about racism are not useful predictors of grades, regardless of major or the prestige of the college. For example, overall, the variable denoting support for affirmative action and the variable indicating support for banning racist/sexist speech is weakly predictive of grades by the end of college. Neither variable shows predictable variation by major. Only the affirmative action variable varies predictably by the prestige of the college, with pro-affirmative students having marginally higher grades at more prestigious institutions. 
It is difficult to know how to interpret the "dissent is critical to the political process" variable because it substantively differs from other political variables in the model. Opinions regarding same-sex marriage, the contemporary threat of racism, abortion rights, and affirmative action are classifiable as liberal or conservative. By contrast, opinions of the value of dissent as a civic value seemingly transcend any one ideological tradition or interest. In a democracy, everyone sometimes may align or ally with a dissenting interest group, political party, or social movement (Whittington 2018). Accordingly, one would expect that students, regardless of ideology, would develop an appreciation for the value of dissent as they progress through college. Indeed, importance of the dissent variable increases when comparing models of grades between high school and college. Perhaps owing to the value conservatives place on authority (Haidt 2012), support for dissent is traditionally stronger among liberals. As a predictor of grades, support for dissent is the strongest among students majoring in the social sciences and practically non-existent among STEM majors, which aligns with research suggesting that engineers, at least, are uncomfortable with dissent and ambiguity (Gambetta and Hertog 2016). That the variable is not significant in the humanities and somewhat significant in the professional majors underscores the fact that, unlike support for abortion rights, this variable does not vary with likely faculty ideology.

Finally, to place results in perspective, we note that whatever the underlying causes, when controlling for SAT scores and demographics, differences between liberal and conservative students are modest. For example, holding all else constant, the most liberal student would enjoy a 0.16 point advantage over the most conservative student on a 7 point scale. Given our large sample size, this difference is statistically significant. Additionally, the liberal advantage varies by discipline (STEM v. social sciences) and by particular policy views, as in the case of abortion. When examining individual policy positions, pro-life students enjoy an advantage over pro-choice students; however, this GPA advantage is far less in college than high school. Additionally, among the politics/policy variables, the second strongest predictor of college grades is a belief that "dissent is critical to the political process." While this variable is more often held by liberal than conservative students, in practice it may be ideologically neutral. Generally, while these results suggest subtle biases in grading, bias is by no means the only explanation for the observed differences.

\section{[Table 5 Here]}

Beyond grades, student politics/policy views are consistently (albeit modestly) predictive of satisfaction with college. Table 6 models five assessments of respondent experience in college at the end of senior year. These evaluations ask students to rate on a four-point scale $(1=$ strongly disagree and $4=$ strongly agree $)$ the extent to which they agree with the following statements:

- "I feel valued at this institution."

- "Faculty believe in my potential to succeed academically."

- "Faculty showed concern about my progress."

- "At least one faculty member has taken an interest in my development."

Unlike GPA, these variables are not largely a function of SAT scores. Perhaps as a result, each has substantially lower explained variance.

As with models of GPA, pro-life students tend to have somewhat higher assessments of their college experience than pro-choice peers. As in the model of student grades, a belief 
that "dissent is critical to the political process" is associated with more satisfaction with college. Unlike the GPA models, other politics/policy positions are important predictors of satisfaction. Given the relative link between student commitment to dissent and positive ratings, ironically, support to ban racist/sexist speech is in two instances ("feel valued" and "believed in my potential") associated with higher satisfaction. Similarly, support for affirmative action is associated with a belief that "I feel valued at this institution" and "faculty showed concern about my progress." While the variable measuring racial discrimination is not associated with grades, it modestly predicts college satisfaction. Students who are more inclined to believe racial discrimination is a problem are less likely to think faculty believed in their potential, and less likely to identify at least one faculty member who took an interest in their success.

Perhaps the most interesting variable in Table 5 relates to support for same-sex marriage. With respect to grades, this variable has no predictive power. However, in rating their college experience, students who support same-sex marriage tend to feel more valued, and believe that faculty see their potential, show concern, and take an interest in their success. Conversely, students opposing same sex marriage tend to disagree on these items. Since the same sex marriage item has no relationship with grades, it is difficult to argue that students holding minority (anti) positions face academic bias. Still, the variable's relationships with variables measuring assessment of relations with faculty opens the possibility that directly or indirectly, opposition to same sex-marriage contributes to alienation among some students. Again, even when the variable has high statistical significance (i.e. "faculty believed in my potential") the substantive effect on the model is small. Further, these items measure student perceptions rather than faculty behavior such as grading. Nonetheless, given political conflict on many campuses (Binder and Wood 2013; Zimmerman 2015), these results warrant further study.

\section{Discussion and Conclusions: Do liberal students enjoy an advantage?}

Elected officials and political activists on both the Left and the Right have very different views of the value and purpose of American higher education. These political disagreements tend to cloud serious discussions about consequences of academia's predominantly left-leaning faculty. Consequently, a finding that grades are strongly tied to objective measures of ability, but are potentially influenced by students' political beliefs, are bound to generate criticisms from multiple sides.

Generally, we find that for all students, SAT scores and demographic variables do far more to predict grades than do ideological variables. That said, controlling for SAT scores and demographics, conservatives report higher than expected grades in high school and lower than expected grades in college relative to liberals. Further, while conservatives report uniformly high satisfaction with college courses, liberals report higher satisfaction with social sciences and humanities than with STEM courses. Students who report valuing dissent and favoring restrictions on free speech report more favorable relationships with faculty, as do students favoring same sex marriage. One interesting exception to the pattern occurs on the abortion item. Pro-life students have higher GPAs, though this advantage fades in the transition from high school to college and disappears completely in elite colleges. All of 
these relationships (save between grades and SATs) are modest, but raise intriguing questions.

First, after controlling for measures of academic ability (SATs) and demographics, why should ideology predict grades? One possible answer is bias in grading. This is not to suggest that faculty consciously discriminate against conservative students. Typically, faculty do not know the political beliefs of their students, rendering conscious discrimination (at least on a large scale) unlikely. Indeed, Binder and Wood (2013) find that some conservative students hide their ideologies from professors. In this way, ideological discrimination differs from racial or gender bias. However, conservative students may have contrarian worldviews rendering it more difficult to understand subjective material as presented by liberal professors. Distinct worldviews might most characterize social conservatives (Rosen 2007). The fact that the decline in conservative student grade point advantage occurs in fields where faculty tend to be most progressive is at least consistent with the bias hypothesis, though the abortion item serves as an outlier (at non-elite campuses).

Alternatively, gaps between liberal and conservative students might merely reflect different learning styles. Rather than political bias, conservatives might earn lower grades if colleges play to the strengths of liberal students. Prior work shows that liberals more deeply value independence and the creation of original works, while conservatives more deeply value family life, community, and loyalty (Kelly-Woessner and Woessner 2009; Haidt 2012). In short, one could interpret findings here as suggesting that as institutions, high schools fit the strengths of conservatives while colleges fit the strengths of liberals. Indeed, the HERI data offer tantalizing hints that liberal and conservative students come to college with different strengths and interests.

\section{[Insert Figure 1 Here]}

The chart on the left of Figure 1 illustrates student GPA and SAT broken down by ideology. Note again, that conservatives report higher grades in high school, while liberal students report higher verbal and writing scores on the SAT. ${ }^{3}$ Coming into college, conservative students do somewhat better in math; liberals on verbal and writing skills. As noted above, four years later, when asked to assess their college courses, conservatives rated each discipline with roughly the same (high) satisfaction, while liberals preferred humanities and social science courses over STEM courses. Higher education is dominated by liberal faculty, most of whom worked their way through the academy as liberal students (Gross 2013; Posselt 2016). If faculty model their teaching styles to correspond to their own strengths and interests, liberal faculty may simply be better equipped to reach liberal students, explaining GPA differences to the degree they occur.

Finally, since conservative activists will be tempted to cherry-pick these findings as proof that conservatives are the victims of ideological discriminating, it is important not to overstate the magnitude of these results. While the propensity of pro-life students to lose their grade advantage over four years in college may be the result of unconscious ideological bias on the part of the faculty, statistically, grading most reflects supposedly objective

\footnotetext{
${ }^{3}$ Consistent with Woessner and Kelly-Woessner (2009) "middle of the road" students consistently show lower scores than liberals and conservatives.
} 
measures of ability. While the slight grade advantage pro-life students enjoy coming out of high school does decline at the end of four years, even at elite institutions, holding pro-life views is not associated with lower grades. Exactly why the pro-life advantage declines is itself an interesting question, requiring additional research, but results do not paint a picture of conservative students under siege. They remain largely satisfied with their college education, and perform nearly as well as, if not better than, their liberal counterparts. While students' political views may play a small role in their overall grades, success in college is more associated with measures of merit, and with demographic variables. Even if some students are the victims of unconscious bias in grading, these results suggest that academic readiness is a far more important predictor of success than students' political views. 


\section{References}

American Association of University Professors. (2007). Freedom in the classroom.

Washington, DC: American Association of University Professors. Retrieved from http://www.aaup.org/AAUP/comm/rep/A/class.htm.

Armstrong, E.A., \& Hamilton, L.T. (2013). Paying for the party. Cambridge, MA: Harvard University Press.

Arum, R. (2003). Judging school discipline. Cambridge, MA: Harvard University Press.

Arum, R., \& Roksa, J. (2011). Academically adrift. Chicago, IL: University of Chicago Press.

Binder, A.J., \& Wood, K. (2013). Becoming right: How campuses shape young conservatives. Princeton, NJ: Princeton University Press.

Callahan, R.E. (1962). Education and the cult of efficiency. Chicago, IL: University of Chicago Press.

Carl, N. (2014). Verbal intelligence is correlated with socially and economically liberal beliefs. Intelligence, 44, 142-148.

Chapman, B., Fiscella, K., Dubenstein, P., Kawachi, I., \& Muennig, P. (2014). Measurement confounding affects the extent to which verbal IQ explains social gradients in mortality. Journal of Epidemiology and Community Health, 68(8), 28-733.

Gambetta, D., \& Hertog, S. (2016). Engineers of jihad. Princeton. NJ: Princeton University Press.

Gerber, A.S., Huber, G.A., Doherty, D., \& Dowling, C.N. 2011. The big five personality traits in the political arena. Annual Review of Political Science, 14, 236-87.

Gross, N. (2013). Why are professors liberal and why do conservatives care? Cambridge, MA: Harvard University Press.

Haidt, J. (2012). The righteous mind: Why good people are divided by politics and religion. New York, NY: Pantheon Books.

Hammack, F.M. (2016). Schooling for social mobility: High school reform for college access and success. Journal of School Choice, 10(1), 96-111.

Jacoby, W.G. (1991). Ideological identification and issue attitudes. American Journal of Political Science, 35(1), 178-205.

Jost, J.T., Napier, J.L., Thorisdottir, H., Gosling, S.D., Palfai, T.P., \& B. Ostafin. (2007). Are needs to manage uncertainty and threat associated with political conservatism or ideological extremity? Personality and Social Psychology Bulletin, 33(7), 9891007.

Kanazawa, S. (2010). Why liberals and atheists are more intelligent. Social Psychology Quarterly, 73(1), 33-57.

Kelly-Woessner, A., \& Woessner, M. (2006). My professor is a partisan hack: How perceptions of a professor's political views affect student course evaluations. $P S$ : Political Science and Politics, 39(3), 495-501.

Klein, D., \& Sternm C. (2009). Groupthink in academia: Majoritarian departmental politics and the professional pyramid. In R. Maranto, R. Redding, \& F. Hess (Eds.), The politically correct university (pp. 79-98). Washington, DC: American Enterprise Institute Press.

Lareau, A. (2003). Unequal childhoods: Race, class, and family life. Berkeley, CA: University of California Press. 
Leeson, P., Heaven, P., \& Ciarrochi, J. (2012). Revisiting the link between low verbal intelligence and ideology. Intelligence, 40(2), 213-216.

Lukianoff, G., \& Haidt, J. (2018). The coddling of the American mind. New York, NY: Penguin Press.

Menand, L. (2010). The marketplace of ideas: reform and resistance in the American university. New York, NY: Norton.

Nathan, R. (2005). My freshman year: What a professor learned by becoming a student. Ithaca, NY: Cornell University Press.

O’Donohue, W., \& R.E. Redding. (2009). The psychology of political correctness in higher education. In R. Maranto, F. Hess, \& R. Redding (Eds.), The politically correct university (pp. 99-120). Washington, DC: American Enterprise Institute Press.

Posselt, J.R. (2016). Inside graduate admissions: Merit, diversity, and faculty gatekeeping. Cambridge, MA: Harvard University Press.

Powell, A.G., E. Farrar \& D. K. Cohen. The Shopping Mall High School. Boston: Houghton-Nifflin.

Reeves, R.V. \& Halikias, D. (2017, March 4). Illiberal arts colleges: Pay more, get less (free speech). Brookings Institution. Retrieved from https://www.brookings.edu/opinions/illiberal-arts-colleges-pay-more-get-lessfree-speech/

Rosen, H.H. (2007). God's Harvard. Orlando, FL: Harcourt Books.

Rothman, S., \& Lichter, S.R. (2009). The vanishing conservative---Is there a glass ceiling? In R. Maranto, F. Hess, \& R. Redding (Eds.), The politically correct university. Washington, DC: American Enterprise Institute Press.

Rousmaniere, K. (2013). The principal's office: A social history of the American school principal. Albany, NY: State University of New York Press.

Schwartz, J.A. (2015). Socioeconomic status as a moderator of the genetic and shared environmental influence on verbal IQ: A multilevel behavioral genetic approach. Intelligence, 52, 80-89.

Shields, J.A., \& Dunn, J.M. (2016). Passing on the right. New York, NY: Oxford University Press.

Tough, P. (2012). How children succeed. New York, NY: Houghton Mifflin.

Warikoo, N.K. (2017). The diversity bargain. Chicago, IL: University of Chicago Press.

Weiss, B. (2017, April 14). Jonathan Haidt on the cultural roots of campus rage. Wall Street Journal. Retrieved from_https://www.wsj.com/articles/jonathan-haidt-on-thecultural-roots-of-campus-rage-1491000676

Whittington, K.E. (2018). Speak freely: Why universities must defend free speech. Princeton, NJ: Princeton University Press.

Woessner, M., \& Kelly-Woessner, A. (2009). Left pipeline: Why conservatives don't get doctorates. In R. Maranto, R. Redding, \& F. Hess (Eds.), The politically correct university: Problems, scope, and reform (pp. 38-59). Washington, DC: American Enterprise Institute Press.

Yancey, G. (2011). Compromising scholarship: Religious and political bias in American higher education. Waco, TX: Baylor University Press.

Zimmerman, J. (2015). Campus politics: What everyone needs to know. New York, NY: Oxford University Press. 
Table 1: Overview of Reported Grades by Ideology \& Political Views

\begin{tabular}{|c|c|c|c|c|c|c|c|c|c|c|c|}
\hline \multirow{6}{*}{$\begin{array}{l}\text { How would } \\
\text { student } \\
\text { characterize } \\
\text { (1st Year) }\end{array}$} & Ideology & $\begin{array}{l}\text { High School } \\
\text { Grades }\end{array}$ & $\begin{array}{l}\text { College } \\
\text { Grades }\end{array}$ & $\begin{array}{c}\text { Net } \\
\text { Change }\end{array}$ & $\mathrm{n}$ & & \multirow{4}{*}{\multicolumn{4}{|c|}{ *HERI grading scale defines "D" = 1 and "A/A+" = 8}} & \\
\hline & Far Right/Con & 6.99 & 6.31 & -0.68 & $\approx 4400$ & & & & & & \\
\hline & Middle & 6.75 & 6.08 & -0.67 & $\approx 6300$ & & & & & & \\
\hline & Lib/Far Left & 6.84 & 6.26 & -0.58 & $\approx 5200$ & & & & & & \\
\hline & \multirow[t]{2}{*}{ Total } & 6.85 & 6.2 & -0.65 & $\approx 15900$ & & & & & & \\
\hline & & High School & College & Net & & \multirow{7}{*}{$\begin{array}{c}\text { "Racial discrimination is } \\
\text { no longer a major } \\
\text { problem in America" } \\
\text { (1st Year) }\end{array}$} & & High School & College & Net & \\
\hline \multirow{6}{*}{$\begin{array}{l}\text { "Same-sex } \\
\text { couples should } \\
\text { have the right } \\
\text { to legal marital } \\
\text { (1st Year) }\end{array}$} & Same Sex Marriage Legality & Grades & Grades & Change & $n$ & & Racism Major Problem & Grades & Grades & Change & $\mathrm{n}$ \\
\hline & Disagree strongly & 6.97 & 6.26 & -0.71 & $\approx 3100$ & & Disagree strongly & 6.79 & 6.13 & -0.66 & $\approx 5000$ \\
\hline & Disagree somewhat & 6.81 & 6.12 & -0.69 & $\approx 2400$ & & Disagree somewhat & 6.87 & 6.24 & -0.63 & $\approx 7800$ \\
\hline & Agree somewhat & 6.8 & 6.09 & -0.71 & $\approx 4000$ & & Agree somewhat & 6.87 & 6.19 & -0.68 & $\approx 3000$ \\
\hline & Agree strongly & 6.82 & 6.27 & -0.55 & $\approx 6700$ & & Agree strongly & 6.77 & 6.21 & -0.56 & $\approx 500$ \\
\hline & Total & 6.84 & 6.2 & -0.64 & $\approx 16300$ & & Total & 6.84 & 6.2 & -0.64 & $\approx 16300$ \\
\hline \multirow{6}{*}{$\begin{array}{l}\text { "Abortion } \\
\text { should be legal" } \\
\text { (1st Year) }\end{array}$} & Abortion Legality & $\begin{array}{c}\text { High School } \\
\text { Grades }\end{array}$ & $\begin{array}{l}\text { College } \\
\text { Grades }\end{array}$ & $\begin{array}{l}\text { Net } \\
\text { Change }\end{array}$ & $\mathrm{n}$ & $\begin{array}{c}\text { "Students from } \\
\text { disadvantaged social }\end{array}$ & Affirmative Action Support & $\begin{array}{l}\text { High School } \\
\text { Grades }\end{array}$ & $\begin{array}{l}\text { College } \\
\text { Grades }\end{array}$ & $\begin{array}{c}\text { Net } \\
\text { Change }\end{array}$ & $\mathrm{n}$ \\
\hline & Disagree strongly & 7.02 & 6.31 & -0.71 & $\approx 4700$ & \multirow{5}{*}{$\begin{array}{l}\text { backgrounds should be } \\
\text { given preferential } \\
\text { treatment in college } \\
\text { admissions" } \\
\text { (1st Year) }\end{array}$} & Disagree strongly & 7.02 & 6.28 & -0.74 & $\approx 4000$ \\
\hline & Disagree somewhat & 6.82 & 6.12 & -0.7 & $\approx 2700$ & & Disagree somewhat & 6.86 & 6.24 & -0.62 & $\approx 6600$ \\
\hline & Agree somewhat & 6.74 & 6.1 & -0.64 & $\approx 4500$ & & Agree somewhat & 6.73 & 6.14 & -0.59 & $\approx 4700$ \\
\hline & Agree strongly & 6.77 & 6.23 & -0.54 & $\approx 4400$ & & Agree strongly & 6.6 & 5.88 & -0.72 & $\approx 600$ \\
\hline & Total & 6.84 & 6.2 & -0.64 & $\approx 16300$ & & Total & 6.85 & 6.21 & -0.64 & $\approx 15900$ \\
\hline \multirow{6}{*}{$\begin{array}{l}\text { "Colleges } \\
\text { should prohibit } \\
\text { racist/sexist } \\
\text { speech on } \\
\text { (1st Year) }\end{array}$} & Stop Racist/Sexist Speech & $\begin{array}{l}\text { High School } \\
\text { Grades }\end{array}$ & $\begin{array}{l}\text { College } \\
\text { Grades }\end{array}$ & $\begin{array}{l}\text { Net } \\
\text { Change }\end{array}$ & $\mathrm{n}$ & \multirow{6}{*}{$\begin{array}{l}\text { "Dissent is a critical } \\
\text { component of the } \\
\text { political process" } \\
\text { (1st Year) }\end{array}$} & Dissent is a Critical & $\begin{array}{l}\text { High School } \\
\text { Grades }\end{array}$ & $\begin{array}{l}\text { College } \\
\text { Grades }\end{array}$ & $\begin{array}{c}\text { Net } \\
\text { Change }\end{array}$ & $\mathrm{n}$ \\
\hline & Disagree strongly & 6.68 & 6.07 & -0.61 & $\approx 1200$ & & Disagree strongly & 6.68 & 6.08 & -0.6 & $\approx 500$ \\
\hline & Disagree somewhat & 6.84 & 6.14 & -0.7 & $\approx 3000$ & & Disagree somewhat & 6.65 & 5.98 & -0.67 & $\approx 4200$ \\
\hline & Agree somewhat & 6.94 & 6.32 & -0.62 & $\approx 5500$ & & Agree somewhat & 6.86 & 6.2 & -0.66 & $\approx 7600$ \\
\hline & Agree strongly & 6.9 & 6.3 & -0.6 & $\approx 5400$ & & Agree strongly & 7.17 & 6.55 & -0.62 & $\approx 2900$ \\
\hline & Total & 6.89 & 6.26 & -0.63 & $\approx 15100$ & & Total & 6.86 & 6.2 & -0.66 & $\approx 15300$ \\
\hline
\end{tabular}


Table 2: Regression Model Predicting Student Grades Using Ideology \& Political Views

\begin{tabular}{|c|c|c|c|c|c|}
\hline \multirow{2}{*}{\multicolumn{2}{|c|}{ Independent Variable }} & \multicolumn{2}{|c|}{ Ideology Model } & \multicolumn{2}{|c|}{ Politics \& Policy Model } \\
\hline & & High School & College & High School & College \\
\hline & Constant & $\begin{array}{l}3.528 * * * \\
(0.123)\end{array}$ & $\begin{array}{l}2.472 * * * \\
(0.160)\end{array}$ & $\begin{array}{l}3.760 * * * \\
(0.139)\end{array}$ & $\begin{array}{l}2.458 * * * \\
(0.180)\end{array}$ \\
\hline \multirow{3}{*}{ 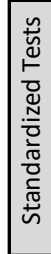 } & SAT (Math) & $\begin{array}{l}3.0 \mathrm{E}-03 * * * \\
(1.64 \mathrm{E}-04)\end{array}$ & $\begin{array}{l}1.6 \mathrm{E}-03 * * * \\
(2.13 \mathrm{E}-04)\end{array}$ & $\begin{array}{l}2.9 \mathrm{E}-03 * * * \\
(1.67 \mathrm{E}-04)\end{array}$ & $\begin{array}{l}1.6 \mathrm{E}-03 * * * \\
(2.17 \mathrm{E}-04)\end{array}$ \\
\hline & SAT (Verbal) & $\begin{array}{l}1.2 \mathrm{E}-03 * * * \\
(1.97 \mathrm{E}-04)\end{array}$ & $\begin{array}{l}1.4 \mathrm{E}-03 * * * \\
(2.55 \mathrm{E}-04)\end{array}$ & $\begin{array}{l}1.0 \mathrm{E}-03 * * * \\
(2.04 \mathrm{E}-04)\end{array}$ & $\begin{array}{l}1.4 \mathrm{E}-03 * * * \\
(2.66 \mathrm{E}-04)\end{array}$ \\
\hline & SAT (Writing) & $\begin{array}{l}1.4 \mathrm{E}-03 \text { *** } \\
(1.96 \mathrm{E}-04)\end{array}$ & $\begin{array}{l}2.0 \mathrm{E}-03 \text { *** } \\
(2.54 \mathrm{E}-04)\end{array}$ & $\begin{array}{l}1.2 \mathrm{E}-03 * * * \\
(1.99 \mathrm{E}-04)\end{array}$ & $\begin{array}{l}1.8 \mathrm{E}-03 * * * \\
(2.59 \mathrm{E}-04)\end{array}$ \\
\hline \multirow{6}{*}{ 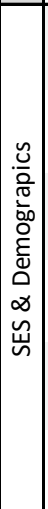 } & Mom Homemaker? & $\begin{array}{l}0.008 \\
(0.040)\end{array}$ & $\begin{array}{l}0.013 \\
(0.051)\end{array}$ & $\begin{array}{r}-0.015 \\
(0.040)\end{array}$ & $\begin{array}{r}-0.015 \\
(0.052)\end{array}$ \\
\hline & Dad Homemaker & $\begin{array}{r}-0.210 \\
(0.188)\end{array}$ & $\begin{array}{r}-0.207 \\
(0.242)\end{array}$ & $\begin{array}{r}-0.197 \\
(0.189)\end{array}$ & $\begin{array}{r}-0.144 \\
(0.248)\end{array}$ \\
\hline & Mom Income (Est) & $\begin{array}{r}-0.005 \\
(0.017)\end{array}$ & $\begin{array}{l}0.006 \\
(0.022)\end{array}$ & $\begin{array}{r}-0.009 \\
(0.017)\end{array}$ & $\begin{array}{l}0.011 \\
(0.022)\end{array}$ \\
\hline & Dad Est Income (Est) & $\begin{array}{l}-0.045 * * \\
(0.015)\end{array}$ & $\begin{array}{r}-0.007 \\
(0.019)\end{array}$ & $\begin{array}{l}-0.043 * * \\
(0.015)\end{array}$ & $\begin{array}{r}-0.009 \\
(0.020)\end{array}$ \\
\hline & Is R Non-White & $\begin{array}{l}-0.152 * * * \\
(0.027)\end{array}$ & $\begin{array}{l}-0.452 * * * \\
(0.035)\end{array}$ & $\begin{array}{l}-0.146 * * * \\
(0.028)\end{array}$ & $\begin{array}{l}-0.4566^{* * *} \\
(0.036)\end{array}$ \\
\hline & Sex & $\begin{array}{l}0.240 * * * \\
(0.024)\end{array}$ & $\begin{array}{l}0.348 * * * \\
(0.031)\end{array}$ & $\begin{array}{l}0.234 * * * \\
(0.024)\end{array}$ & $\begin{array}{l}0.360^{* * *} \\
(0.032)\end{array}$ \\
\hline \multirow{4}{*}{$\begin{array}{l}\frac{0}{0} \\
\frac{2}{20} \\
\frac{0}{8} \\
\frac{d}{0}\end{array}$} & Mom PID (Est) & $\begin{array}{r}2.2 \mathrm{E}-04 \\
(8.14 \mathrm{E}-04)\end{array}$ & $\begin{array}{l}-6.5 \mathrm{E}-04 \\
(1.06 \mathrm{E}-03)\end{array}$ & $\begin{array}{r}2.7 \mathrm{E}-04 \\
(8.28 \mathrm{E}-04)\end{array}$ & $\begin{array}{r}-1.7 \mathrm{E}-04 \\
(1.08 \mathrm{E}-03)\end{array}$ \\
\hline & Dad PID (Est) & $\begin{array}{r}7.7 \mathrm{E}-04 \\
(8.89 \mathrm{E}-04)\end{array}$ & $\begin{array}{l}3.3 \mathrm{E}-03 * * \\
(1.16 \mathrm{E}-03)\end{array}$ & $\begin{array}{r}1.1 \mathrm{E}-03 \\
(9.01 \mathrm{E}-04)\end{array}$ & $\begin{array}{l}3.4 \mathrm{E}-03 * * \\
(1.17 \mathrm{E}-03)\end{array}$ \\
\hline & Ideological Strength & $\begin{array}{r}-0.012 \\
(0.020)\end{array}$ & $\begin{array}{l}0.004 \\
(0.026)\end{array}$ & $\begin{array}{r}-0.019 \\
(0.021)\end{array}$ & $\begin{array}{l}0.020 \\
(0.027)\end{array}$ \\
\hline & Ideological Self-Placement & $\begin{array}{l}-0.079 * * * \\
(0.013)\end{array}$ & $\begin{array}{l}0.040 * \\
(0.018)\end{array}$ & & \\
\hline \multirow{6}{*}{ 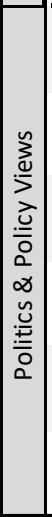 } & Pro same-sex marriage & & & $\begin{array}{r}-0.013 \\
(0.013)\end{array}$ & $\begin{array}{l}0.012 \\
(0.020)\end{array}$ \\
\hline & Racial discrim is no longer a problem & & & $\begin{array}{r}-1.4 \mathrm{E}-02 \\
(0.015)\end{array}$ & $\begin{array}{r}1.7 \mathrm{E}-03 \\
(0.019)\end{array}$ \\
\hline & Abortion should be legal & & & $\begin{array}{l}-0.113^{* * *} \\
(0.012)\end{array}$ & $\begin{array}{l}-0.088^{* * *} \\
(0.017)\end{array}$ \\
\hline & Favors affirmative action & & & $\begin{array}{r}-0.022 \\
(0.014)\end{array}$ & $\begin{array}{l}0.036 * \\
(0.018)\end{array}$ \\
\hline & $\begin{array}{l}\text { Colleges should ban racist/sexist } \\
\text { speech }\end{array}$ & & & $\begin{array}{l}0.025 * \\
(0.012)\end{array}$ & $\begin{array}{l}0.040 * \\
(0.016)\end{array}$ \\
\hline & $\begin{array}{l}\text { Dissent is critical to the political } \\
\text { process }\end{array}$ & & & $\begin{array}{c}4.4 \mathrm{E}-02 * * \\
(0.016)\end{array}$ & $\begin{array}{l}7.4 \mathrm{E}-02 * * * \\
(0.022)\end{array}$ \\
\hline & $\mathrm{n}$ & 7062 & 7207 & 6380 & 7000 \\
\hline & Adjusted $\mathrm{R}^{2}$ & 0.185 & 0.135 & 0.189 & 0.137 \\
\hline & $* p<=0.05$ & $* * p<=.01$ & $* * * p<=.001$ & & \\
\hline
\end{tabular}


Table 3: Regression Model Predicting Student Grades Using Politics \& Policy Views

\begin{tabular}{|c|c|c|c|c|c|c|c|c|c|}
\hline \multirow{2}{*}{\multicolumn{2}{|c|}{ Independent Variable }} & \multicolumn{2}{|c|}{ Arts and Humanities } & \multicolumn{2}{|c|}{ Social Sciences } & \multicolumn{2}{|c|}{ Professional } & \multicolumn{2}{|c|}{ Natural Sciences } \\
\hline & & High School & College & High School & College & High School & College & High School & College \\
\hline \multirow{4}{*}{ 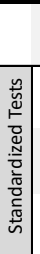 } & Constant & $\begin{array}{l}3.812^{* * *} \\
(0.319)\end{array}$ & $\begin{array}{l}2.922^{* * *} \\
(0.393)\end{array}$ & $\begin{array}{l}3.417^{* * *} \\
(0.307)\end{array}$ & $\begin{array}{l}1.466^{* * *} \\
(0.388)\end{array}$ & $\begin{array}{l}3.504 * * * \\
(0.234)\end{array}$ & $\begin{array}{l}2.973^{* * *} \\
(0.302)\end{array}$ & $\begin{array}{l}4.818^{* * *} \\
(0.294)\end{array}$ & $\begin{array}{l}1.770^{* * *} \\
(0.439)\end{array}$ \\
\hline & SAT (Math) & $\begin{array}{l}1.36 \mathrm{E}-03^{* * *} \\
(0.000)\end{array}$ & $\begin{array}{r}2.27 \mathrm{E}-04 \\
4.8 \mathrm{E}-04\end{array}$ & $\begin{array}{l}2.06 \mathrm{E}-03^{* * *} \\
(0.000)\end{array}$ & $\begin{array}{c}1.15 \mathrm{E}-03^{*} \\
4.9 \mathrm{E}-04\end{array}$ & $\begin{array}{l}3.67 \mathrm{E}-03 * * * \\
\quad(0.000)\end{array}$ & $\begin{array}{c}\text { 1.99E-03 } * * * \\
3.7 \mathrm{E}-04\end{array}$ & $\begin{array}{l}2.38 \mathrm{E}-03 * * * \\
\quad(0.000)\end{array}$ & $\begin{array}{l}3.16 \mathrm{E}-03 * * * \\
5.2 \mathrm{E}-04\end{array}$ \\
\hline & SAT (Verbal) & $\begin{array}{c}1.39 \mathrm{E}-03^{* *} \\
(0.000)\end{array}$ & $\begin{array}{c}1.11 \mathrm{E}-03 \text { * } \\
5.4 \mathrm{E}-04\end{array}$ & $\begin{array}{l}1.55 \mathrm{E}-03^{* * *} \\
(0.000)\end{array}$ & $\begin{array}{l}2.31 \mathrm{E}-03 \text { *** } \\
5.7 \mathrm{E}-04\end{array}$ & $\begin{array}{c}9.27 \mathrm{E}-04 * * \\
(0.000)\end{array}$ & $\begin{array}{c}9.49 \mathrm{E}-04 * \\
4.7 \mathrm{E}-04\end{array}$ & $\begin{array}{c}1.03 \mathrm{E}-03 * \\
(0.000)\end{array}$ & $\begin{array}{c}1.38 \mathrm{E}-03^{*} \\
6.1 \mathrm{E}-04\end{array}$ \\
\hline & SAT (Writing) & $\begin{array}{l}1.65 \mathrm{E}-03^{* * *} \\
(0.000)\end{array}$ & $\begin{array}{l}2.83 \mathrm{E}-03 \text { *** } \\
5.5 \mathrm{E}-04\end{array}$ & $\begin{array}{c}1.35 \mathrm{E}-03^{* *} \\
(0.000)\end{array}$ & $\begin{array}{l}1.84 \mathrm{E}-03 \text { *** } \\
5.4 \mathrm{E}-04\end{array}$ & $\begin{array}{c}1.02 \mathrm{E}-03 * * \\
(0.000)\end{array}$ & $\begin{array}{c}1.22 \mathrm{E}-03^{* *} \\
4.3 \mathrm{E}-04\end{array}$ & $\begin{array}{l}1.16 \mathrm{E}-03 * * \\
(0.000)\end{array}$ & $\begin{array}{l}2.20 \mathrm{E}-03^{* * *} \\
6.0 \mathrm{E}-04\end{array}$ \\
\hline \multirow{6}{*}{ 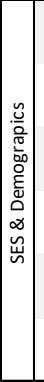 } & Mom Homemaker? & $\begin{array}{l}0.081 \\
(0.093)\end{array}$ & $\begin{array}{r}-0.001 \\
(0.113)\end{array}$ & $\begin{array}{l}0.000 \\
(0.089)\end{array}$ & $\begin{array}{l}0.009 \\
(0.111)\end{array}$ & $\begin{array}{r}-0.030 \\
(0.064)\end{array}$ & $\begin{array}{r}-0.034 \\
(0.085)\end{array}$ & $\begin{array}{r}-0.064 \\
(0.083)\end{array}$ & $\begin{array}{r}-0.051 \\
(0.122)\end{array}$ \\
\hline & Dad Homemaker? & $\begin{array}{l}0.303 \\
(0.417)\end{array}$ & $\begin{array}{l}0.327 \\
(0.485)\end{array}$ & $\begin{array}{l}0.452 \\
(0.922)\end{array}$ & $\begin{array}{r}-1.959 \\
(1.197)\end{array}$ & $\begin{array}{r}-0.446 \\
(0.244)\end{array}$ & $\begin{array}{r}-0.152 \\
(0.331)\end{array}$ & $\begin{array}{l}0.277 \\
(0.477)\end{array}$ & $\begin{array}{r}-0.160 \\
(0.719)\end{array}$ \\
\hline & Mom Income (Est) & $\begin{array}{l}0.043 \\
(0.040)\end{array}$ & $\begin{array}{l}0.052 \\
(0.048)\end{array}$ & $\begin{array}{r}-0.004 \\
(0.038)\end{array}$ & $\begin{array}{l}0.103 * \\
(0.048)\end{array}$ & $\begin{array}{r}-0.027 \\
(0.028)\end{array}$ & $\begin{array}{r}-0.033 \\
(0.037)\end{array}$ & $\begin{array}{r}-0.027 \\
(0.036)\end{array}$ & $\begin{array}{r}-0.040 \\
(0.052)\end{array}$ \\
\hline & Dad Est Income (Est) & $\begin{array}{r}-0.001 \\
(0.035)\end{array}$ & $\begin{array}{r}-0.024 \\
(0.043)\end{array}$ & $\begin{array}{r}-0.052 \\
(0.032)\end{array}$ & $\begin{array}{r}-0.026 \\
(0.041)\end{array}$ & $\begin{array}{r}-0.045 \\
(0.025)\end{array}$ & $\begin{array}{l}0.048 \\
(0.033)\end{array}$ & $\begin{array}{r}-0.057 \\
(0.032)\end{array}$ & $\begin{array}{r}-0.069 \\
(0.046)\end{array}$ \\
\hline & Is R Non-White & $\begin{array}{l}-0.198^{* *} \\
(0.065)\end{array}$ & $\begin{array}{l}-0.408^{* * *} \\
(0.079)\end{array}$ & $\begin{array}{r}-0.078 \\
(0.059)\end{array}$ & $\begin{array}{l}-0.334^{* * *} \\
(0.073)\end{array}$ & $\begin{array}{l}-0.149 * * \\
(0.046)\end{array}$ & $\begin{array}{l}-0.522^{* * *} \\
(0.060)\end{array}$ & $\begin{array}{l}-0.199 * * * \\
(0.058)\end{array}$ & $\begin{array}{l}-0.482^{* * *} \\
(0.082)\end{array}$ \\
\hline & Sex & $\begin{array}{l}0.202^{* * *} \\
(0.058)\end{array}$ & $\begin{array}{l}0.381^{* * *} \\
(0.072)\end{array}$ & $\begin{array}{l}0.324^{* * *} \\
(0.054)\end{array}$ & $\begin{array}{l}0.525^{* * *} \\
(0.070)\end{array}$ & $\begin{array}{l}0.251 * * * \\
(0.040)\end{array}$ & $\begin{array}{l}0.379^{* * *} \\
(0.053)\end{array}$ & $\begin{array}{l}0.178 * * * \\
(0.049)\end{array}$ & $\begin{array}{l}0.155^{*} \\
(0.071)\end{array}$ \\
\hline \multirow{3}{*}{$\left|\begin{array}{c}\frac{0}{0} \\
\frac{b}{0.0} \\
\frac{0}{0} \\
\frac{d}{0}\end{array}\right|$} & Mom PID (Est) & $\begin{array}{r}3.89 \mathrm{E}-04 \\
(0.002)\end{array}$ & $\begin{array}{r}-1.72 \mathrm{E}-05 \\
2.3 \mathrm{E}-03\end{array}$ & $\begin{array}{r}2.32 \mathrm{E}-03 \\
(0.002)\end{array}$ & $\begin{array}{r}1.86 \mathrm{E}-03 \\
2.3 \mathrm{E}-03\end{array}$ & $\begin{array}{r}-2.98 \mathrm{E}-04 \\
(0.001)\end{array}$ & $\begin{array}{r}-2.67 \mathrm{E}-03 \\
1.8 \mathrm{E}-03\end{array}$ & $\begin{array}{r}2.04 \mathrm{E}-04 \\
(0.002)\end{array}$ & $\begin{array}{r}1.76 \mathrm{E}-04 \\
2.4 \mathrm{E}-03\end{array}$ \\
\hline & Dad PID (Est) & $\begin{array}{r}5.04 \mathrm{E}-05 \\
(0.002)\end{array}$ & $\begin{array}{r}2.70 \mathrm{E}-03 \\
2.4 \mathrm{E}-03\end{array}$ & $\begin{array}{r}6.59 \mathrm{E}-04 \\
(0.002)\end{array}$ & $\begin{array}{r}2.46 \mathrm{E}-03 \\
2.5 \mathrm{E}-03\end{array}$ & $\begin{array}{r}1.80 \mathrm{E}-03 \\
(0.002)\end{array}$ & $\begin{array}{l}5.42 \mathrm{E}-03 \text { ** } \\
2.1 \mathrm{E}-03\end{array}$ & $\begin{array}{r}-8.35 \mathrm{E}-05 \\
(0.002)\end{array}$ & $\begin{array}{r}2.45 \mathrm{E}-04 \\
2.6 \mathrm{E}-03\end{array}$ \\
\hline & Ideological Strength & $\begin{array}{l}0.061 \\
(0.047)\end{array}$ & $\begin{array}{r}-0.005 \\
(0.058)\end{array}$ & $\begin{array}{l}0.030 \\
(0.045)\end{array}$ & $\begin{array}{l}0.143^{*} \\
(0.056)\end{array}$ & $\begin{array}{r}-0.062 \\
(0.034)\end{array}$ & $\begin{array}{r}-0.040 \\
(0.045)\end{array}$ & $\begin{array}{r}-0.063 \\
(0.044)\end{array}$ & $\begin{array}{r}-0.020 \\
(0.062)\end{array}$ \\
\hline \multirow{6}{*}{ 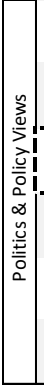 } & Pro same-sex marriage & $\begin{array}{r}-0.025 \\
(0.032)\end{array}$ & $\begin{array}{l}-0.038 \\
4.9 E-02\end{array}$ & $\begin{array}{l}0.020 \\
(0.029)\end{array}$ & $\begin{array}{r}-0.041 \\
4.7 \mathrm{E}-02\end{array}$ & $\begin{array}{r}-0.015 \\
(0.020)\end{array}$ & $\begin{array}{r}0.021 \\
3.1 \mathrm{E}-02\end{array}$ & $\begin{array}{r}-0.037 \\
(0.027)\end{array}$ & $\begin{array}{r}0.094 \\
5.0 \mathrm{E}-02\end{array}$ \\
\hline & $\begin{array}{l}\text { Racial discrim is no } \\
\text { longer a problem }\end{array}$ & $\begin{array}{r}-0.038 \\
(0.035) \\
\end{array}$ & $\begin{array}{r}-0.040 \\
(0.043)\end{array}$ & $\begin{array}{r}0.011 \\
(0.033) \\
\end{array}$ & $\begin{array}{r}-0.025 \\
(0.042) \\
\end{array}$ & $\begin{array}{r}-0.012 \\
(0.025) \\
\end{array}$ & $\begin{array}{l}0.021 \\
(0.031) \\
\end{array}$ & $\begin{array}{r}-0.030 \\
(0.031)\end{array}$ & $\begin{array}{l}0.049 \\
(0.045)\end{array}$ \\
\hline & Abortion should be legal & $\begin{array}{l}-0.141361 \\
(0.027)\end{array}$ & $\begin{array}{r}-0.06446 \\
3.7 \mathrm{E}-02\end{array}$ & $\begin{array}{c}-0.113573^{* * *} \\
(0.026)\end{array}$ & $\begin{array}{c}-0.074895 *- \\
3.6 \mathrm{E}-02\end{array}$ & $\begin{array}{c}-0 . \overline{12} 174 * * * \\
(0.019)\end{array}$ & $\begin{array}{c}-0.102001 \\
2.7 \mathrm{E}-02\end{array}$ & $\begin{array}{c}-0.07943 * * \\
(0.026)\end{array}$ & $-0.11365^{* *}$ \\
\hline & Favors affirmative action & $\begin{array}{l}0.009 \\
(0.033)\end{array}$ & $\begin{array}{l}0.064 \\
(0.039)\end{array}$ & $\begin{array}{r}-0.011 \\
(0.032)\end{array}$ & $\begin{array}{l}0.047 \\
(0.037)\end{array}$ & $\begin{array}{l}-0.030 \\
(0.024)\end{array}$ & $\begin{array}{r}-0.003 \\
(0.031)\end{array}$ & $\begin{array}{r}-0.047 \\
(0.029)\end{array}$ & $\begin{array}{l}0.053 \\
(0.041)\end{array}$ \\
\hline & $\begin{array}{l}\text { Colleges should ban } \\
\text { racist/sexist speech }\end{array}$ & $\begin{array}{r}0.0353416 \\
(0.028)\end{array}$ & $\begin{array}{r}0.054723 \\
3.5 \mathrm{E}-02\end{array}$ & $\begin{array}{r}-0.000485 \\
(0.027)\end{array}$ & $\begin{array}{r}0.0262693 \\
3.4 \mathrm{E}-02\end{array}$ & $\begin{array}{r}0.036601 \\
(0.020)\end{array}$ & $\begin{array}{r}0.0195617 \\
2.6 \mathrm{E}-02\end{array}$ & $\begin{array}{r}-0.00427 \\
(0.026)\end{array}$ & $\begin{array}{r}0.0602554 \\
3.6 \mathrm{E}-02\end{array}$ \\
\hline & $\begin{array}{l}\text { Dissent is critical to the } \\
\text { political process }\end{array}$ & $\begin{array}{l}0.092^{*} \\
(0.036)\end{array}$ & $\begin{array}{l}0.074 \\
(0.048)\end{array}$ & $\begin{array}{l}0.028 \\
(0.035)\end{array}$ & $\begin{array}{l}0.1222^{* *} \\
(0.045)\end{array}$ & $\begin{array}{l}0.041 \\
(0.027)\end{array}$ & $\begin{array}{l}0.086^{*} \\
(0.036)\end{array}$ & $\begin{array}{l}0.032 \\
(0.034)\end{array}$ & $\begin{array}{l}0.008 \\
(0.052)\end{array}$ \\
\hline & $n$ & 1248 & 1362 & 1398 & 1495 & 2372 & 2673 & 1258 & 1363 \\
\hline \multirow{2}{*}{\multicolumn{2}{|c|}{ Adjusted $\mathrm{R}^{2}$}} & 0.175 & 0.137 & 0.167 & 0.182 & 0.224 & 0.121 & 0.149 & 0.147 \\
\hline & & & & $=0.05$ & $p<-.0$ & & & & \\
\hline
\end{tabular}


Table 4: Regression Model Predicting Student Grades Using Politics \& Policy Views

\begin{tabular}{|c|c|c|c|c|c|c|c|}
\hline \multirow{2}{*}{\multicolumn{2}{|c|}{ Independent Variable }} & \multicolumn{2}{|c|}{$<$ High } & \multicolumn{2}{|c|}{ High } & \multicolumn{2}{|c|}{ Very High } \\
\hline & & High School & College & High School & College & High School & College \\
\hline & Constant & $\begin{array}{l}3.335^{* * *} \\
(0.453)\end{array}$ & $\begin{array}{l}1.880^{* * *} \\
(0.503)\end{array}$ & $\begin{array}{l}4.084^{* * *} \\
(0.212)\end{array}$ & $\begin{array}{l}1.3411^{* * *} \\
(0.276)\end{array}$ & $\begin{array}{l}4.342 * * * \\
(0.250)\end{array}$ & $\begin{array}{l}1.016^{* *} \\
(0.353)\end{array}$ \\
\hline \multirow{3}{*}{ 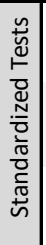 } & SAT (Math) & $\begin{array}{c}4.04 \mathrm{E}-03^{* * *} \\
(0.000)\end{array}$ & $\begin{array}{c}1.89 \mathrm{E}-03^{* * *} \\
5.6 \mathrm{E}-04\end{array}$ & $\begin{array}{c}2.71 \mathrm{E}-03^{* * *} \\
(0.000)\end{array}$ & $\begin{array}{c}2.59 \mathrm{E}-03^{* * *} \\
3.1 \mathrm{E}-04\end{array}$ & $\begin{array}{c}2.14 \mathrm{E}-03 * * * \\
(0.000)\end{array}$ & $\begin{array}{c}1.82 \mathrm{E}-03^{* * *} \\
3.8 \mathrm{E}-04\end{array}$ \\
\hline & SAT (Verbal) & $\begin{array}{r}3.92 \mathrm{E}-04 \\
(0.001)\end{array}$ & $\begin{array}{r}9.79 \mathrm{E}-04 \\
7.9 \mathrm{E}-04\end{array}$ & $\begin{array}{c}7.46 \mathrm{E}-04^{*} \\
(0.000)\end{array}$ & $\begin{array}{c}2.09 \mathrm{E}-03^{* * *} \\
3.7 \mathrm{E}-04\end{array}$ & $\begin{array}{c}1.36 \mathrm{E}-03 * * * \\
(0.000)\end{array}$ & $\begin{array}{c}1.77 \mathrm{E}-03^{* * *} \\
4.3 \mathrm{E}-04\end{array}$ \\
\hline & SAT (Writing) & $\begin{array}{c}1.33 \mathrm{E}-03 \text { * } \\
(0.001)\end{array}$ & $\begin{array}{c}1.85 \mathrm{E}-03 \text { * } \\
7.4 \mathrm{E}-04\end{array}$ & $\begin{array}{c}1.20 \mathrm{E}-03^{* * *} \\
(0.000)\end{array}$ & $\begin{array}{c}2.09 \mathrm{E}-03^{* * *} \\
3.6 \mathrm{E}-04\end{array}$ & $\begin{array}{c}8.90 \mathrm{E}-044^{* *} \\
\quad(0.000)\end{array}$ & $\begin{array}{c}2.58 \mathrm{E}-03^{* * *} \\
4.3 \mathrm{E}-04\end{array}$ \\
\hline \multirow{6}{*}{ 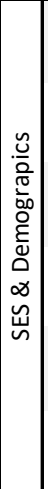 } & Mom Homemaker? & $\begin{array}{l}0.043 \\
(0.133)\end{array}$ & $\begin{array}{l}0.014 \\
(0.155)\end{array}$ & $\begin{array}{r}-0.059 \\
(0.057)\end{array}$ & $\begin{array}{l}0.030 \\
(0.073)\end{array}$ & $\begin{array}{l}0.023 \\
(0.058)\end{array}$ & $\begin{array}{r}-0.016 \\
(0.082)\end{array}$ \\
\hline & Dad Homemaker? & $\begin{array}{l}0.221 \\
(0.498)\end{array}$ & $\begin{array}{l}0.365 \\
(0.569)\end{array}$ & $\begin{array}{r}-0.311 \\
(0.291)\end{array}$ & $\begin{array}{c}-0.738 * \\
(0.370)\end{array}$ & $\begin{array}{r}-0.258 \\
(0.273)\end{array}$ & $\begin{array}{l}0.300 \\
(0.404)\end{array}$ \\
\hline & Mom Income (Est) & $\begin{array}{r}-0.025 \\
(0.062)\end{array}$ & $\begin{array}{l}0.035 \\
(0.068)\end{array}$ & $\begin{array}{l}0.006 \\
(0.024)\end{array}$ & $\begin{array}{l}0.036 \\
(0.031)\end{array}$ & $\begin{array}{r}-0.034 \\
(0.025)\end{array}$ & $\begin{array}{l}0.007 \\
(0.036)\end{array}$ \\
\hline & Dad Est Income (Est) & $\begin{array}{r}-0.021 \\
(0.053)\end{array}$ & $\begin{array}{l}0.075 \\
(0.060)\end{array}$ & $\begin{array}{l}-0.0711^{* * *} \\
(0.021)\end{array}$ & $\begin{array}{r}-0.039 \\
(0.027)\end{array}$ & $\begin{array}{r}-0.020 \\
(0.022)\end{array}$ & $\begin{array}{l}0.073^{*} \\
(0.032)\end{array}$ \\
\hline & Is R Non-White & $\begin{array}{c}-0.2111^{*} \\
(0.087)\end{array}$ & $\begin{array}{l}-0.743^{* * *} \\
(0.099)\end{array}$ & $\begin{array}{l}-0.181^{* * *} \\
(0.040)\end{array}$ & $\begin{array}{l}-0.382^{* * *} \\
(0.052)\end{array}$ & $\begin{array}{c}-0.100 * \\
(0.039)\end{array}$ & $\begin{array}{l}-0.338^{* * *} \\
(0.055)\end{array}$ \\
\hline & Sex & $\begin{array}{l}0.582^{* * *} \\
(0.085)\end{array}$ & $\begin{array}{l}0.654^{* * *} \\
(0.094)\end{array}$ & $\begin{array}{l}0.245^{* * *} \\
(0.034)\end{array}$ & $\begin{array}{l}0.368^{* * *} \\
(0.045)\end{array}$ & $\begin{array}{l}0.093 * * \\
(0.035)\end{array}$ & $\begin{array}{l}0.169^{* * *} \\
(0.050)\end{array}$ \\
\hline \multirow{3}{*}{$\begin{array}{l}\frac{0}{0} \\
\frac{0}{0} \\
\text { 흥 } \\
\frac{0}{0} \\
\frac{d}{0}\end{array}$} & Mom PID (Est) & $\begin{array}{r}2.94 \mathrm{E}-03 \\
(0.003)\end{array}$ & $\begin{array}{r}1.44 \mathrm{E}-03 \\
3.2 \mathrm{E}-03\end{array}$ & $\begin{array}{r}-1.92 \mathrm{E}-03 \\
(0.001)\end{array}$ & $\begin{array}{r}-9.01 \mathrm{E}-04 \\
1.5 \mathrm{E}-03\end{array}$ & $\begin{array}{c}2.76 \mathrm{E}-03 * \\
(0.001)\end{array}$ & $\begin{array}{r}7.03 E-04 \\
1.7 E-03\end{array}$ \\
\hline & Dad PID (Est) & $\begin{array}{r}2.65 \mathrm{E}-03 \\
(0.003)\end{array}$ & $\begin{array}{r}3.67 \mathrm{E}-03 \\
3.5 \mathrm{E}-03\end{array}$ & $\begin{array}{r}5.04 \mathrm{E}-04 \\
(0.001)\end{array}$ & $\begin{array}{r}2.33 \mathrm{E}-03 \\
1.7 \mathrm{E}-03\end{array}$ & $\begin{array}{r}1.01 \mathrm{E}-03 \\
(0.001)\end{array}$ & $\begin{array}{c}4.28 \mathrm{E}-03 \\
1.8 \mathrm{E}-03\end{array}$ \\
\hline & Ideological Strength & $\begin{array}{l}-0.297^{* * *} \\
(0.068)\end{array}$ & $\begin{array}{l}0.015 \\
(0.078)\end{array}$ & $\begin{array}{l}0.015 \\
(0.029)\end{array}$ & $\begin{array}{l}0.013 \\
(0.037)\end{array}$ & $\begin{array}{l}0.021 \\
(0.030)\end{array}$ & $\begin{array}{l}0.074 \\
(0.042)\end{array}$ \\
\hline \multirow{6}{*}{ 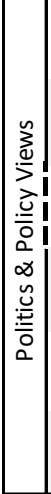 } & Pro same-sex marriage & $\begin{array}{c}-0.080 * \\
(0.040)\end{array}$ & $\begin{array}{r}0.031 \\
5.1 E-02\end{array}$ & $\begin{array}{l}0.002 \\
(0.018)\end{array}$ & $\begin{array}{r}0.009 \\
2.8 \mathrm{E}-02\end{array}$ & $\begin{array}{r}-0.026 \\
(0.020)\end{array}$ & $\begin{array}{r}0.030 \\
3.5 \mathrm{E}-02\end{array}$ \\
\hline & $\begin{array}{l}\text { Racial discrim is no } \\
\text { longer a problem }\end{array}$ & $\begin{array}{l}0.019 \\
(0.050)\end{array}$ & $\begin{array}{l}0.066 \\
(0.054) \\
\end{array}$ & 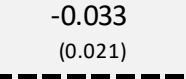 & 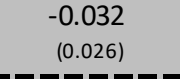 & $\begin{array}{l}0.005 \\
(0.022)\end{array}$ & $\begin{array}{l}0.023 \\
(0.031)\end{array}$ \\
\hline & Abortion should be legal & $-0.079^{*}$ & $\begin{array}{l}-0.154^{* *} \\
4.7 \mathrm{E}-02\end{array}$ & $\begin{array}{l}-0.118^{* * *} \\
(0.017)\end{array}$ & $\begin{array}{l}-0.079^{* * *} \\
2.3 \mathrm{E}-02\end{array}$ & $(0.018)$ & $\begin{array}{l}-0.044 \\
2.7 \mathrm{E}-02 \\
-\end{array}$ \\
\hline & Favors affirmative action & $\begin{array}{l}-0.131^{* *} \\
(0.046)\end{array}$ & $\begin{array}{r}-0.001 \\
(0.052)\end{array}$ & $\begin{array}{l}0.014 \\
(0.020)\end{array}$ & $\begin{array}{l}0.050^{*} \\
(0.025)\end{array}$ & $\begin{array}{c}-0.044 * \\
(0.021)\end{array}$ & $\begin{array}{l}0.063 \\
(0.029)\end{array}$ \\
\hline & $\begin{array}{l}\text { Colleges should ban } \\
\text { racist/sexist speech }\end{array}$ & $\begin{array}{l}0.033 \\
(0.039)\end{array}$ & $\begin{array}{l}0.097^{*} \\
4.6 \mathrm{E}-02\end{array}$ & $\begin{array}{l}0.036^{*} \\
(0.017)\end{array}$ & $\begin{array}{r}0.035 \\
2.1 \mathrm{E}-02\end{array}$ & $\begin{array}{l}0.009 \\
(0.019)\end{array}$ & $\begin{array}{r}0.030 \\
2.6 \mathrm{E}-02\end{array}$ \\
\hline & $\begin{array}{l}\text { Dissent is critical to the } \\
\text { political process }\end{array}$ & $\begin{array}{l}0.001 \\
(0.055)\end{array}$ & $\begin{array}{l}0.126^{*} \\
(0.059)\end{array}$ & $\begin{array}{l}0.033 \\
(0.022)\end{array}$ & $\begin{array}{l}0.078^{* *} \\
(0.029)\end{array}$ & $\begin{array}{l}0.067 * * \\
(0.025)\end{array}$ & $\begin{array}{l}0.072^{*} \\
(0.036)\end{array}$ \\
\hline & $\mathrm{n}$ & 881 & 1074 & 3278 & 3543 & 2216 & 2379 \\
\hline & Adjusted $\mathrm{R}^{2}$ & 0.202 & 0.182 & 0.130 & 0.159 & 0.165 & 0.145 \\
\hline & & & $=0.05$ & $* * * \mathrm{p}<=.001$ & & & \\
\hline
\end{tabular}


Table 5: Regression Model Predicting Assessments of College Experience

\begin{tabular}{|c|c|c|c|c|c|c|c|}
\hline \multicolumn{2}{|c|}{ Independent Variable } & Grades & $\begin{array}{l}\text { Feel Valued } \\
\text { at this School } \\
\end{array}$ & $\begin{array}{l}\text { Fac Believed } \\
\text { My Potential }\end{array}$ & $\begin{array}{l}\text { Fac Provided } \\
\text { Letter of Rec }\end{array}$ & $\begin{array}{r}\text { Fac Showed } \\
\text { Concern } \\
\end{array}$ & $\begin{array}{c}\text { At Least One Fac } \\
\text { Interest in Me }\end{array}$ \\
\hline & Constant & $\begin{array}{l}2.458^{* * *} \\
(0.180)\end{array}$ & $\begin{array}{l}2.373^{* * *} \\
(0.104)\end{array}$ & $\begin{array}{l}2.574^{* * *} \\
(0.088)\end{array}$ & $\begin{array}{l}1.587^{* * *} \\
(0.097)\end{array}$ & $\begin{array}{l}2.613^{* * *} \\
(0.111)\end{array}$ & $\begin{array}{l}2.522^{* * *} \\
(0.092)\end{array}$ \\
\hline \multirow{3}{*}{ 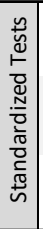 } & SAT (Math) & $\begin{array}{l}1.6 \mathrm{E}-03^{* * *} \\
2.2 \mathrm{E}-04\end{array}$ & $\begin{array}{c}3.8 \mathrm{E}-044^{* *} \\
1.2 \mathrm{E}-04\end{array}$ & $\begin{array}{r}6.4 \mathrm{E}-05 \\
1.1 \mathrm{E}-04\end{array}$ & $\begin{array}{r}-2.0 \mathrm{E}-04 \\
1.2 \mathrm{E}-04\end{array}$ & $\begin{array}{c}-5.5 \mathrm{E}-04^{* * *} \\
1.3 \mathrm{E}-04\end{array}$ & $\begin{array}{r}-5.0 \mathrm{E}-05 \\
1.1 \mathrm{E}-04\end{array}$ \\
\hline & SAT (Verbal) & $\begin{array}{l}1.4 \mathrm{E}-03^{* * *} \\
2.7 \mathrm{E}-04\end{array}$ & $\begin{array}{r}1.0 \mathrm{E}-04 \\
1.5 \mathrm{E}-04\end{array}$ & $\begin{array}{c}3.3 \mathrm{E}-04 \\
1.3 \mathrm{E}-04\end{array}$ & $\begin{array}{r}2.6 \mathrm{E}-04 \\
1.4 \mathrm{E}-04\end{array}$ & $\begin{array}{c}5.8 \mathrm{E}-04^{* * *} \\
1.6 \mathrm{E}-04\end{array}$ & $\begin{array}{r}1.5 \mathrm{E}-04 \\
1.4 \mathrm{E}-04\end{array}$ \\
\hline & SAT (Writing) & $\begin{array}{l}1.8 \mathrm{E}-03^{* * *} \\
2.6 \mathrm{E}-04\end{array}$ & $\begin{array}{r}2.8 \mathrm{E}-04 \\
1.5 \mathrm{E}-04\end{array}$ & $\begin{array}{r}2.1 \mathrm{E}-04 \\
1.3 \mathrm{E}-04\end{array}$ & $\begin{array}{r}-2.1 \mathrm{E}-05 \\
1.4 \mathrm{E}-04\end{array}$ & $\begin{array}{r}2.4 \mathrm{E}-04 \\
1.6 \mathrm{E}-04\end{array}$ & $\begin{array}{c}3.9 \mathrm{E}-044^{* *} \\
1.3 \mathrm{E}-04\end{array}$ \\
\hline \multirow{6}{*}{ 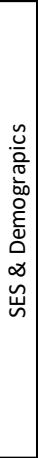 } & Mom Homemaker? & $\begin{array}{r}-0.015 \\
(0.052)\end{array}$ & $\begin{array}{r}-0.020 \\
(0.030)\end{array}$ & $\begin{array}{r}-0.041 \\
(0.025)\end{array}$ & $\begin{array}{c}-0.071^{*} \\
(0.028)\end{array}$ & $\begin{array}{l}0.003 \\
(0.032)\end{array}$ & $\begin{array}{r}-0.027 \\
(0.027)\end{array}$ \\
\hline & Dad Homemaker & $\begin{array}{r}-0.144 \\
(0.248)\end{array}$ & $\begin{array}{l}0.077 \\
(0.143)\end{array}$ & $\begin{array}{l}0.018 \\
(0.121)\end{array}$ & $\begin{array}{l}0.034 \\
(0.133)\end{array}$ & $\begin{array}{r}-0.032 \\
(0.152)\end{array}$ & $\begin{array}{r}-0.243 \\
(0.127)\end{array}$ \\
\hline & Mom Income (Est) & $\begin{array}{l}0.011 \\
(0.022)\end{array}$ & $\begin{array}{l}0.011 \\
(0.013)\end{array}$ & $\begin{array}{l}0.008 \\
(0.011)\end{array}$ & $\begin{array}{r}-0.004 \\
(0.012)\end{array}$ & $\begin{array}{l}0.004 \\
(0.014)\end{array}$ & $\begin{array}{l}0.014 \\
(0.012)\end{array}$ \\
\hline & Dad Est Income (Est) & $\begin{array}{r}-0.009 \\
(0.020)\end{array}$ & $\begin{array}{l}0.033^{* *} \\
(0.011)\end{array}$ & $\begin{array}{l}0.014 \\
(0.010)\end{array}$ & $\begin{array}{l}0.030 \text { ** } \\
(0.011)\end{array}$ & $\begin{array}{r}-0.003 \\
(0.012)\end{array}$ & $\begin{array}{l}0.013 \\
(0.010)\end{array}$ \\
\hline & Is R Non-White & $\begin{array}{l}-0.4566^{* * *} \\
(0.036)\end{array}$ & $\begin{array}{l}-0.133^{* * *} \\
(0.021)\end{array}$ & $\begin{array}{l}-0.098^{* * *} \\
(0.017)\end{array}$ & $\begin{array}{r}-0.034 \\
(0.019)\end{array}$ & $\begin{array}{l}-0.054^{*} \\
(0.022)\end{array}$ & $\begin{array}{l}-0.080^{* * *} \\
(0.018)\end{array}$ \\
\hline & Sex & $\begin{array}{l}0.360^{* * *} \\
(0.032)\end{array}$ & $\begin{array}{l}0.098^{* * *} \\
(0.018)\end{array}$ & $\begin{array}{l}0.078^{* * *} \\
(0.016)\end{array}$ & $\begin{array}{l}0.164^{* * *} \\
(0.017)\end{array}$ & $\begin{array}{l}0.036 \\
(0.020)\end{array}$ & $\begin{array}{l}0.098^{* * *} \\
(0.016)\end{array}$ \\
\hline \multirow{4}{*}{$\begin{array}{l}\text { 음 } \\
\text { o. } \\
\frac{0}{0} \\
\underline{0} \\
\underline{0}\end{array}$} & Mom PID (Est) & $\begin{array}{r}-1.7 \mathrm{E}-04 \\
1.1 \mathrm{E}-03\end{array}$ & $\begin{array}{r}-3.2 \mathrm{E}-04 \\
6.2 \mathrm{E}-04\end{array}$ & $\begin{array}{r}-8.6 \mathrm{E}-04 \\
5.3 \mathrm{E}-04\end{array}$ & $\begin{array}{r}-4.1 \mathrm{E}-04 \\
5.8 \mathrm{E}-04\end{array}$ & $\begin{array}{r}-2.2 \mathrm{E}-04 \\
6.6 \mathrm{E}-04\end{array}$ & $\begin{array}{r}-2.2 \mathrm{E}-05 \\
5.5 \mathrm{E}-04\end{array}$ \\
\hline & Dad PID (Est) & $\begin{array}{l}3.4 \mathrm{E}-033^{* *} \\
1.2 \mathrm{E}-03\end{array}$ & $\begin{array}{r}3.4 \mathrm{E}-04 \\
6.7 \mathrm{E}-04\end{array}$ & $\begin{array}{r}7.9 \mathrm{E}-04 \\
5.7 \mathrm{E}-04\end{array}$ & $\begin{array}{l}2.1 \mathrm{E}-03^{* * *} \\
6.3 \mathrm{E}-04\end{array}$ & $\begin{array}{r}9.6 \mathrm{E}-04 \\
7.2 \mathrm{E}-04\end{array}$ & $\begin{array}{r}5.1 \mathrm{E}-04 \\
6.0 \mathrm{E}-04\end{array}$ \\
\hline & Ideological Strength & $\begin{array}{l}0.020 \\
(0.027)\end{array}$ & $\begin{array}{l}0.001 \\
(0.015)\end{array}$ & $\begin{array}{l}0.031 * \\
(0.013)\end{array}$ & $\begin{array}{l}0.012 \\
(0.014)\end{array}$ & $\begin{array}{r}-0.006 \\
(0.016)\end{array}$ & $\begin{array}{l}0.048^{* * *} \\
(0.014)\end{array}$ \\
\hline & Ideological Self-Placement & & & & & & \\
\hline \multirow{6}{*}{ 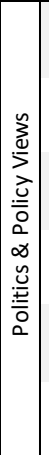 } & Pro same-sex marriage & $\begin{array}{l}0.012 \\
(0.020)\end{array}$ & $\begin{array}{l}0.028^{*} \\
(0.012)\end{array}$ & $\begin{array}{l}0.036^{* * *} \\
(0.010)\end{array}$ & $\begin{array}{l}0.035^{* *} \\
(0.011)\end{array}$ & $\begin{array}{l}0.027^{*} \\
(0.013)\end{array}$ & $\begin{array}{l}0.035^{* * *} \\
(0.010)\end{array}$ \\
\hline & Racial discrim is no longer a problem & $\begin{array}{l}0.002 \\
(0.019)\end{array}$ & $\begin{array}{l}0.006 \\
(0.011)\end{array}$ & $\begin{array}{c}-0.019{ }^{*} \\
(0.009)\end{array}$ & $\begin{array}{l}0.019 \\
(0.010)\end{array}$ & $\begin{array}{r}-0.005 \\
(0.012)\end{array}$ & $\begin{array}{c}-0.021{ }^{*} \\
(0.010)\end{array}$ \\
\hline & Abortion should be legal & $\begin{array}{l}-0.088^{* * *} \\
(0.017)\end{array}$ & $\begin{array}{l}-0.073^{* * *} \\
(0.010)\end{array}$ & $\begin{array}{l}-0.047^{* * *} \\
(0.008)\end{array}$ & $\begin{array}{l}-0.033^{* * *} \\
(0.009)\end{array}$ & $\begin{array}{l}-0.047^{* * *} \\
(0.010)\end{array}$ & $\begin{array}{l}-0.039^{* * *} \\
(0.009)\end{array}$ \\
\hline & Favors affirmative action & $\begin{array}{l}0.036^{*} \\
(0.018)\end{array}$ & $\begin{array}{l}0.024 \\
(0.010)\end{array}$ & $\begin{array}{l}0.008 \\
(0.009)\end{array}$ & $\begin{array}{l}0.027^{* *} \\
(0.010)\end{array}$ & $\begin{array}{l}0.023 * \\
(0.011)\end{array}$ & $\begin{array}{l}0.017 \\
(0.009)\end{array}$ \\
\hline & Colleges should ban racist/sexist speech & $\begin{array}{l}0.040^{*} \\
(0.016)\end{array}$ & $\begin{array}{l}0.026^{* *} \\
(0.009)\end{array}$ & $\begin{array}{l}0.023 \text { ** } \\
(0.008)\end{array}$ & $\begin{array}{r}-0.004 \\
(0.008)\end{array}$ & $\begin{array}{l}0.014 \\
(0.010)\end{array}$ & $\begin{array}{l}0.014 \\
(0.008)\end{array}$ \\
\hline & Dissent is critical to the political process & $\begin{array}{l}0.074^{* * *} \\
(0.022)\end{array}$ & $\begin{array}{l}0.057^{* * *} \\
(0.012)\end{array}$ & $\begin{array}{l}0.082^{* * *} \\
(0.011)\end{array}$ & $\begin{array}{l}0.044^{* * *} \\
(0.012)\end{array}$ & $\begin{array}{l}0.067^{* * *} \\
(0.013)\end{array}$ & $\begin{array}{l}0.077^{* * *} \\
(0.011)\end{array}$ \\
\hline & $\mathrm{n}$ & 7000 & 7013 & 7014 & 7013 & 7006 & 7008 \\
\hline \multirow{2}{*}{\multicolumn{2}{|c|}{ Adjusted $\mathrm{R}^{2}$}} & 0.137 & 0.034 & 0.041 & 0.024 & 0.017 & 0.036 \\
\hline & & ${ }^{*} \mathrm{p}<=0.05$ & $* * p<=.01$ & $* * * p<=.001$ & & & \\
\hline
\end{tabular}


Figure 1: SAT Scores, High School Grades and Assessments of College Course Work by Ideology
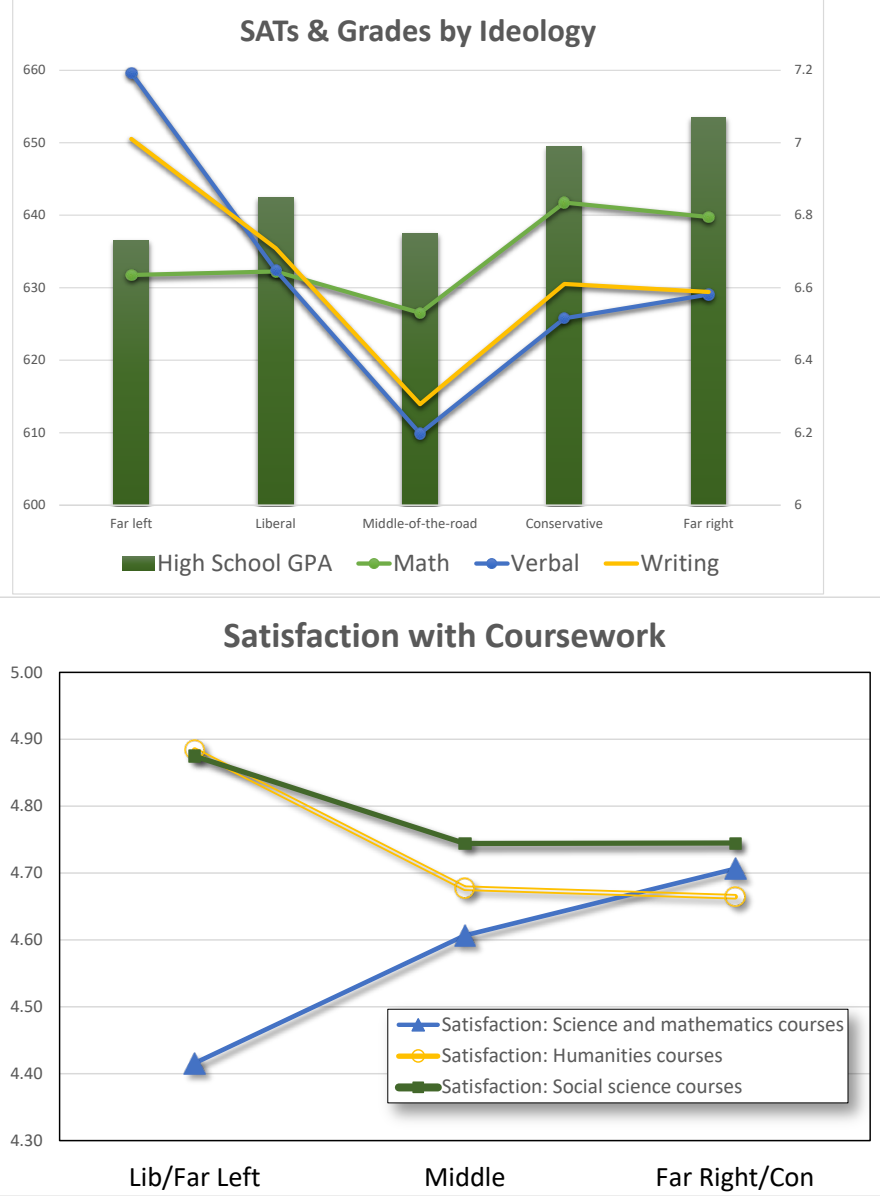